Tests for Determining Impact Resistance and Strength of Glass Used for Nuclear Waste Disposal

L. R. Bunnell

May 1979

Prepared for the U.S. Department of Energy under Contract EY-76-C-06-1830

Pacific Northwest Laboratory Operated for the U.S. Department of Energy by Battelle Memorial Institute 
This report was prepared as an account of work sponsored by the United States Covernment. Neither the United States nor the Department of Energy, nor any of their employees, nor any of their contractors, subcontractors, or their employees, makes any warranty, express or implied, or assumes any legal liability or responsibility for the accuracy, completeness or usefuiness of any iniormation, apparatus, product or prccess disclosed, or represents that its use would not infringe privately owned rights.

The views, opinions and conciusions contained in this report are those of the contractor and do rot necessariiy represent those of the United States Covernment or the United States Department of Energy.

\author{
PACIFIC NORTHWEST LABORATORY \\ operated by \\ BATTELLE \\ for the \\ UNITED STATES DEPARTMENT OF ENERGY \\ Under Contract EY-76-C-06-1830
}

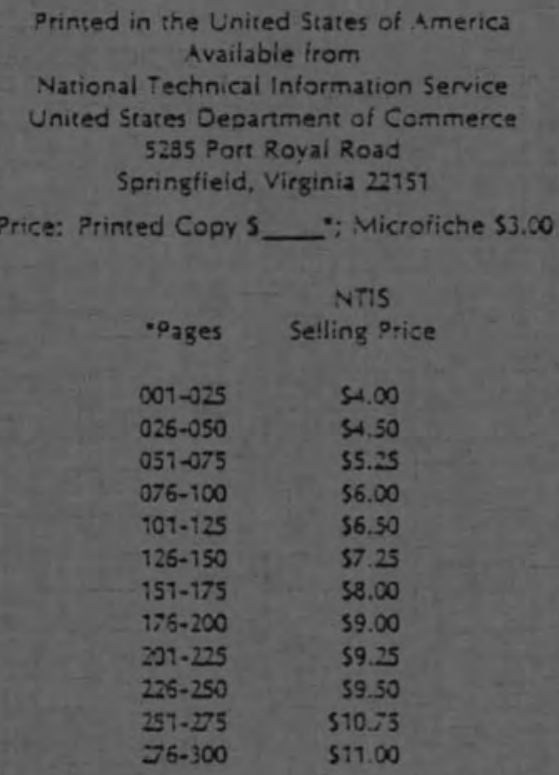




\title{
TESTS FOR DETERMINING IMPACT RESISTANCE AND STRENGTH OF GLASS USED FOR NUCLEAR WASTE DISPOSAL
}

\author{
L. R. BUNNELL
}

MAY, 1979

Prepared for the

U. S. Department of Energy

under contract EY-76-C-06-1830

Pacific Northwest Laboratory

Richland, Washington 99352 


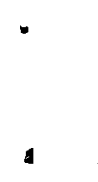




\section{SUMMARY}

Tests are described for determining the impact resistance (Section A) and static tensile strength (Section B) of glasses containing simulated or actual nuclear wastes. This report describes the development and use of these tests to rank different glasses, to assess effects of devitrification, and to examine the effect of impact energy on resulting surface area. For clarity this report is divided into two sections, Impact Resistance and Tensile Strength. 


\section{TABLE OF CONTENTS}

SUMMARY

LIST OF FIGURES

A. IMPACT RESISTANCE

A.I INTRODUCTION

A.2 EXPERIMENTAL

A.3 RESULTS AND DISCUSSION

A.3.1 Ranking of Glasses as a Function of Impact Energy.

i i i

iv

A.3.2 Multiple Impact Damage . $\quad$. $\quad$. $\quad$. $\quad$. 4

A.3.3 Specimen L/D Ratio • . . . . . . 7

A.3.4 Energy Equivalence Experiment $\quad$. $\quad$. $\quad$. $\quad$. 9

A.3.5 Effect of Devitrification on Impact Properties . 9

A.3.6 Surface Area as a Function of Impact Energy . $\quad 12$

A.3.7 Fine Particle Sizes Produced by Impact . . . 13

A.3.8 Glass Ranking . . . . . . . . . 14

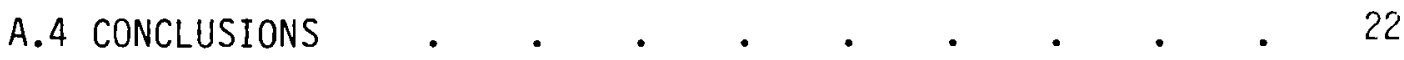

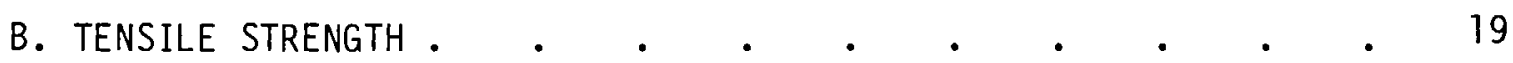

B.I INTRODUCTION

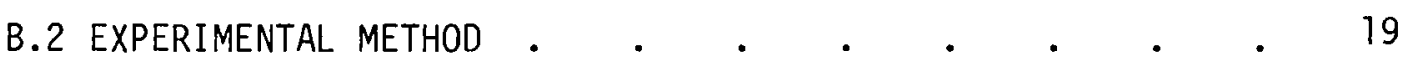

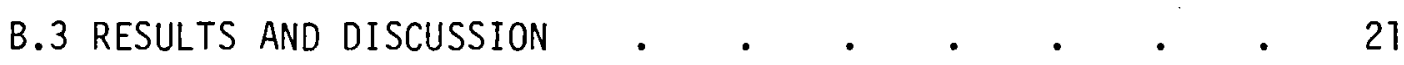

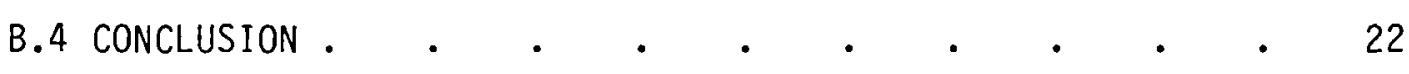

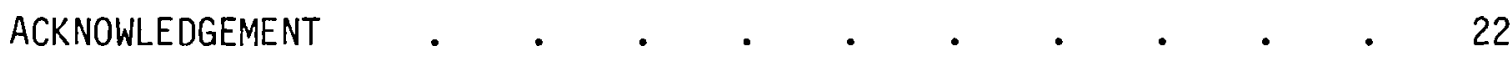

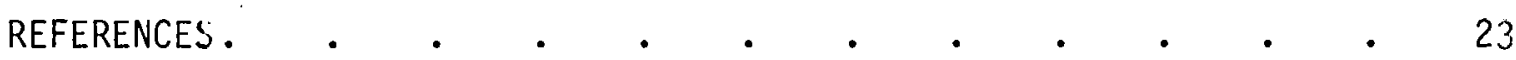

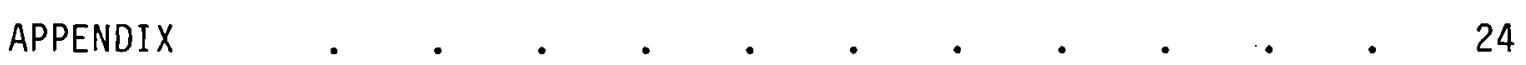

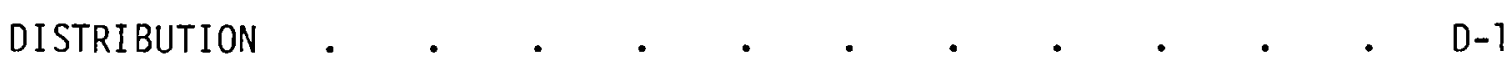




\section{LIST OF FIGURES}

1. Drawing of the impact machine. The weight is constrained on linear bearings.

2. Sectional view of the punch and die arrangement.

3. Sieve analysis results for three glasses, over a range of impact energies.

4. Sieve analysis results of multiple-impact testing.

5. Sieve analysis results on soda-lime-silica glass of various $L / D$ ratios. The inset shows (calculated) surface area as a function of $L / D$ ratio.

6. Sieve analysis results of equivalent energy delivered at different hammer velocity.

7. Sieve analysis results for vitreous and devitrified Corning 9617 glass at several impact energies.

8. Sieve analysis results for Type 77-260 glass in the vitreous and devitrified state.

9. B.E.T. surface area as a function of impact energy for soda-lime-silica and ICM-11 glass.

10. Subsieve size analysis for two glasses impacted in the lab test, as well as glass sampled from an actual drop test.

11. Plot of sieving data on a fairly wide variety of glasses.

12. Impact damage plotted as a function of silica content.

13. Impact damage plotted as a function of $0 / S i$ ratio.

14. Sieve sizing data for three typical glasses, compared to Gaussian distribution.

15. Diagram of experimental arrangement used in Brazilian Splitting Tensile Test. 


\section{A. IMPACT RESISTANCE}

\section{A.1 INTRODUCTION}

Among the various means of disposing of high-level radioactive wastes, a leading candidate at present is to incorporate them into a glass and place this glass in a metal canister of quite large size, of the order $0.6 \mathrm{~m}$ in diameter and $3 \mathrm{~m}$ long. As a consequence of accidents during handling and shipping it is possible that an occasional canister could undergo impact. If an unprotected canister interacts with a hard unyielding surface, its mass assures that the glass will be severely damaged in the impact area. The loss of respirable or dispersible fine particles then depends on (1) whether such fines are generated by impact, (2) the integrity of the canister, i.e., whether it is breached by the impact, and (3) the external environment, such as moving air or water.

Only the first of these is addressed here, since it is a property of the waste form itself. The second and third are so dependent on canister design and local conditions as to be more readily addressed by other disciplines.

The purpose of this work was to develop and assess a laboratory method for evaluating the impact resistance of simulated and actual waste-containing glasses. As a laboratory test, it is recognized that the approach would be limited to comparing different glass types and to perhaps be useful in comparing glass to other candidate waste forms. It is not intended that this work would replace large-scale drop tests using actual large canisters filled with simulated waste glasses. Those tests have been done in the past (1) and cannot be completely replaced by the more idealized laboratory test. The lab-scale impact test should at least decrease the number of large-scale tests which are done because it should provide a means to judge whether small composition or processing changes are likely to have a major effect on impact characteristics.

\section{A.2 EXPERIMENTAL METHOD}

The general approach taken in this work is similar to that used by other groups in the field of radioactive waste disposal. $(2,3)$ A glass specimen, 
usually in the form of a right circular cylinder, is placed in a cavity between a hardened steel punch and die, and a known weight falling through a known distance is used to impact the glass. A drawing of the impact machine is shown in Figure 1 , and Figure 2 shows the die. The cavity in the die is left purposely large to preclude any constraint or support provided by the die. Thus, the specimen is assumed to absorb most of the impact energy and is converted to a compact of powder in the bottom of the die. Except when otherwise noted, the specimen was always $1.2 \mathrm{~cm}$ long and $1.1 \mathrm{~cm}$ diameter, and was impacted as shown in Fiqure 2.

The large die size relative to the specimen diameter resulted in a quantity of air being expelled from the die during impact; this tended to pump fine particles, amounting to $>1 \%$ of the sample mass. An aluminum foil hood was useful in decreasing losses, but retrieval of particles from the wrinkled foil was difficult. The final solution was to machine swirl chambers into the punch to provide a zone of lower air velocity. These chambers decreased sample loss to $<0.4 \%$, which was regarded as acceptable.

The prime method for evaluating the size of particles $>37 \mu \mathrm{m}$ was by sieving. The type of sifter used* was well adapted to small sample quantities and fine particles. The glass shards were shaped such that screen blinding was a significant problem; glass could not be quantitatively removed for weighing except ultrasonically, so screens were weighed each time before sieving and then subtracted from the weight of screen plus glass. The sieving results were then plotted as percent finer than a given size and appear extensively in this report. The scatter amona results on a given glass type was $\pm 5 \%$.

Sieving was quite ineffective for the particles below 325 mesh $(44 \mu \mathrm{m})$ which are of the most interest for dispersibility. When screens to $5 \mu \mathrm{m}$ were tried, agglomeration was a severe problem; a sedimentation techniquet was used. In this method, the particles were allowed to settle in a column of a suitable liquid, and the attenuation of an $x$-ray beam passing through the liquid and suspended particles was measured. By means of Stokes' Law, an

*Sonic Sifter, ATM Corp., Milwaukee, WI.

tSedigraph 5000, Micromeretics Corp., Norcross, GA. 


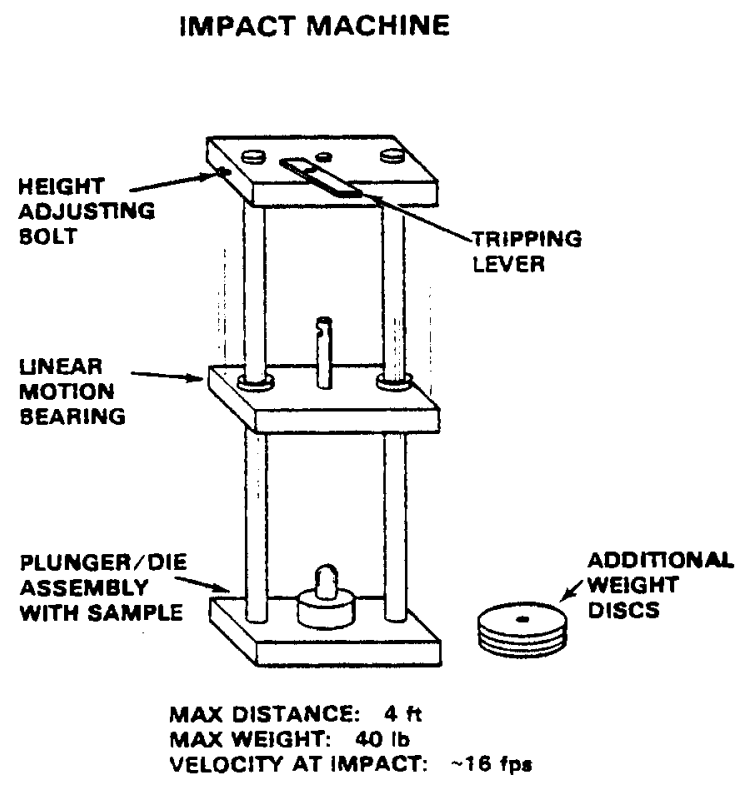

Figure 1. Drawing of the impact machine. The weight is constrained on linear bearings

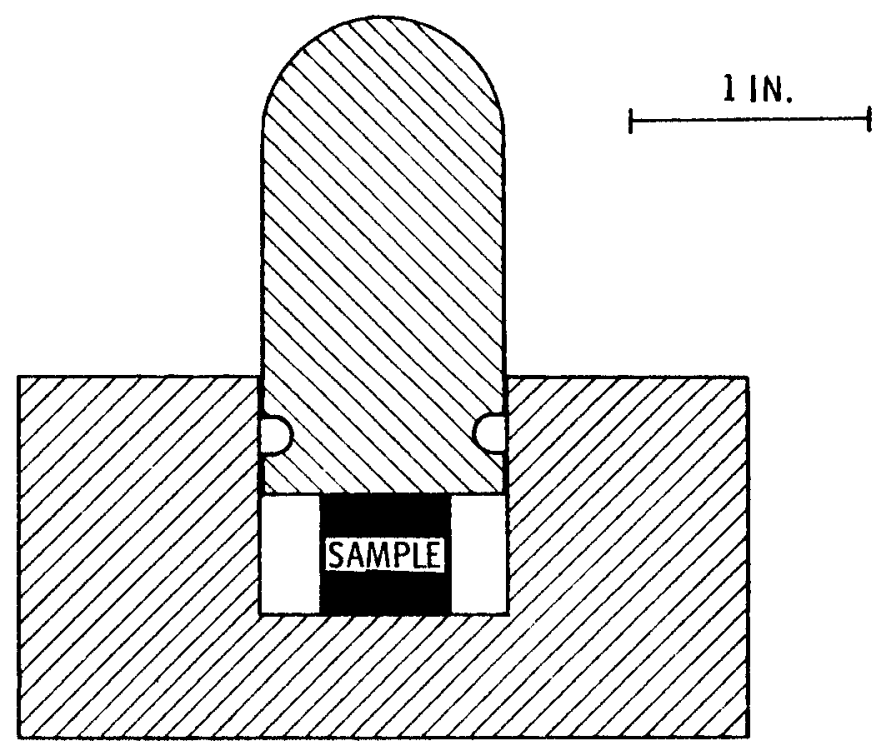

Figure 2. Sectional view of the punch and die arrangment. The insets shown in the punch are swirl chambers. 
equivalent spherical diameter was calculated. The device works well in the less than $100 \mu \mathrm{m}$ range and can detect particles to a size limit determined by the density and the settling time allowed by the experimenter. This method was used to assess the dispersible fraction $(<10 \mu \mathrm{m})$ produced in our tests. It is estimated to be accurate to $\pm 15 \%$ and reproducible to $\pm 5 \%$.

The surface area created by impact is a critical parameter in leaching performance, so this quantity was determined by using the standard B.E.T. (Brunauer, Emmett and Teller) method. We were particularly interested in the relationship between surface area and the impact energy, so this property was measured over a wide range of impact energies for several glasses.

\section{A.3 EXPERIMENTAL RESULTS AND DISCUSSION}

\section{A.3.1 Ranking of Glasses as a Function of Impact Energy.}

Three model glasses, fused silica, soda-lime-silica plate glass, and 73-1* frit, were used to examine the effects of varying impact energy over an order of magnitude. Figure 3 shows the results. It is seen that the ranking of these three glasses is not changed over this range of energies, and fused silica is always the worst performer (greatest fine particle production), while 73-1 frit is always best. Since impact energies during handling/ transportation accidents are expected to be $10^{5}-10^{6} \mathrm{~J}$, the $217 \mathrm{~J}(160 \mathrm{ft}-1 \mathrm{~b})$ limit of the machine was used extensively as a standard impact energy. At the $217 \mathrm{~J} l$ imit, the weight was moving its fastest at $4.88 \mathrm{~m} / \mathrm{sec}(16 \mathrm{ft} / \mathrm{sec})$ and is thus closest to a relevant impact velocity.

\section{A.3.2 Multiple Impact Damage.}

It has been reported ${ }^{(2)}$ that multiple low-energy impacts can be used to approximate high-energy single impacts. In view of the large geometrical difference between the solid right circular cylinder of the first impact and the bed of powder of the subsequent impacts, this contention appeared suspect.

\footnotetext{
*For convenience, glass compositions have been referred to by number designations having only local meaning. The Appendix contains a table of chemical compositions. Table 1 gives a brief description of the glasses.
} 


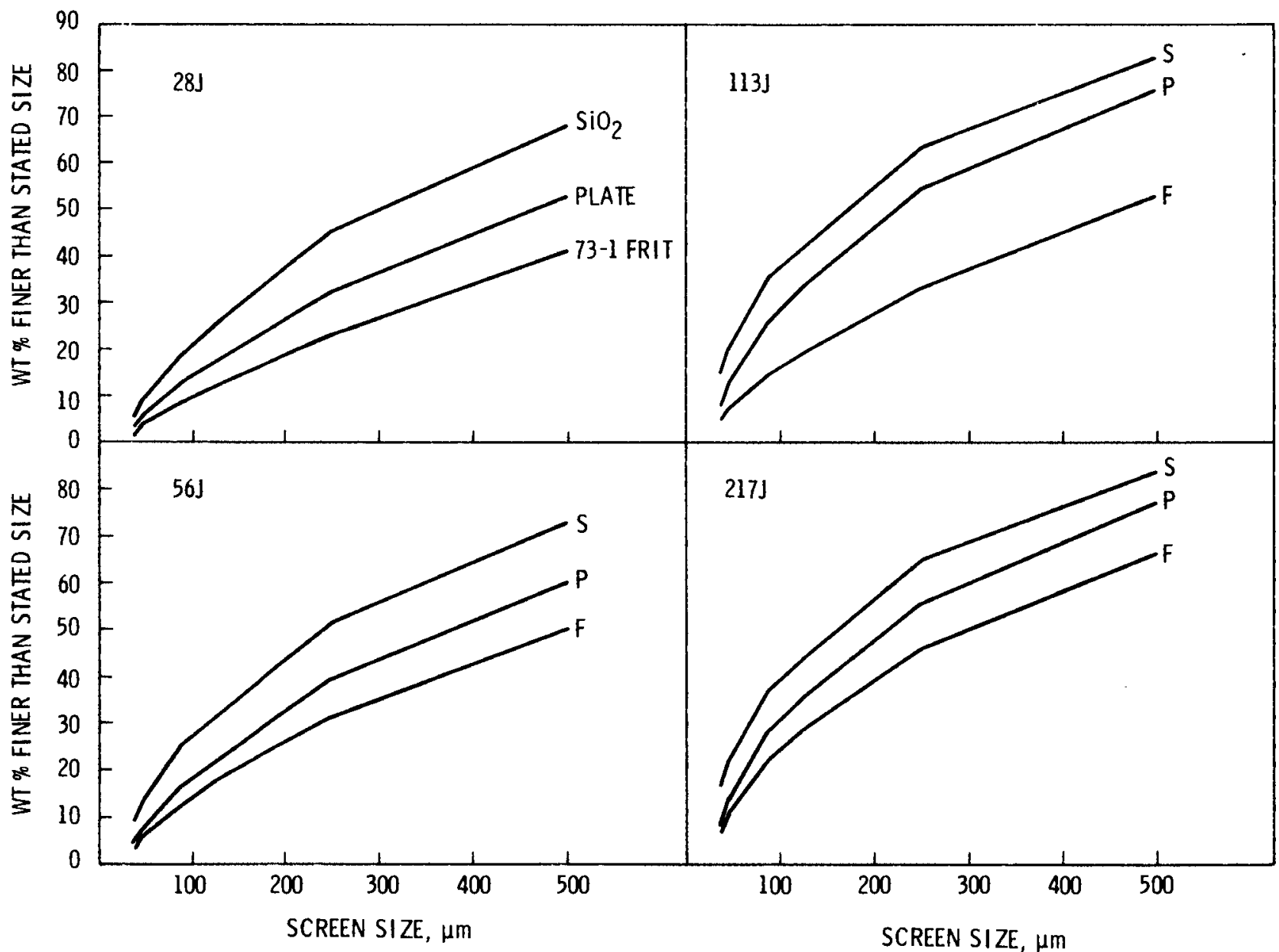

Figure 3. Sieve analysis results for three glasses, over a range of impact energies. Lines are drawn through data averaged over three impacts; scatter was typically $\pm 5 \%$. 
TABLE 1. Brief Description of Glasses which Were Impact Tested

Designation

72-68 (Vitreous)

Fused $\mathrm{SiO}_{2}$

77-GM-09

72-G-004

$77-0 M-01$

$76-68$

$77-260$ (Vitreous)

Soda-Lime-Silica

ICM-11

$73-1$

$76-101$

\section{Description}

Nonradioactive candidate waste glass made with 73-1 frit and one of the Pw-4b calcines.

Commercially available fused silica obtained as transparent sheet.

Natural volcanic glass, Glass Mountain, Siskiyou County, CA., 500 yr. old.

Natural volcanic glass, Long Valley Caldera, Moro County, CA., 70,000 yr. old. Natural volcanic glass, Obsidian Mound, Moro County, CA., 5000 yr. old.

Nonradioactive candidate waste glass made with 76-101 frit and PW-8a-3 calcine.

Nonradioactive version of the AGNS glass composition.

Commercially available window (plate) glass.

The glass used in In-Can-Melter Test \#11. Composition was PW-7-2 calcine and 73-1 frit, $1: 2$.

The frit used to produce $72-68$ glass.

The frit used to produce $76-68$ glass. 
As a test, the same amount of energy, $217 \mathrm{~J}(160 \mathrm{ft}-1 \mathrm{~b})$ was delivered to a sample of soda-lime-silica glass as $1,2,3,4$ or 8 impacts, varying the weight/height combination to produce equal damage energies. The bed of particles was stirred after each impact to increase the potential for damage. The velocity of the hammer varied, of course, with height, but not by more than a factor of two $(4.88 \mathrm{~m} / \mathrm{sec}$ versus $2.44 \mathrm{~m} / \mathrm{sec})$. Figure 4 shows the size fractions produced in this test; the results are certainly not equivalent and show the expected particle grinding effect. After two impacts, the results are closely grouped, reflecting the decreasing efficiency of generating particles. Multiple low-energy impacts do not appear to be a workable means to approximate high energy single impact events.

\section{A.3.3 Specimen L/D Ratio}

In a single-blow impact test, the length/diameter ratio (L/D) of the specimen could influence the results. Since the test method might be applied to different geometries, it was considered important to know how specimen geometry affected the results. A rod of soda-lime-silica glass, $1.3 \mathrm{~cm}$ diameter, was obtained and cut into different lengths, from 0.64 to $6.4 \mathrm{~cm}$. These were impacted in a special long die at a constant energy of 193J $(142 \mathrm{ft}-1 \mathrm{~b})$. The results are plotted in Figure 5 . It is seen that the L/D has a fairly large influence on the results; an order-of-magnitude change in $L / D$ ratio changed the weight percent finer than $100 \mu \mathrm{m}$ by a factor of about 3 .

Surface areas of the powders can be calculated based on sieve analys is and the assumption of perfect spheres. As shown in the insert in Figure 5 , the efficiency of surface area production drops as sample length increases. For the purposes of all testing reported here, the sample length was held at $1.2 \mathrm{~cm} \times 1.1 \mathrm{~cm}$ diameter. If that was impossible, soda-lime-silica glass identical to the specimen was used to help establish a link to existing resuits. 


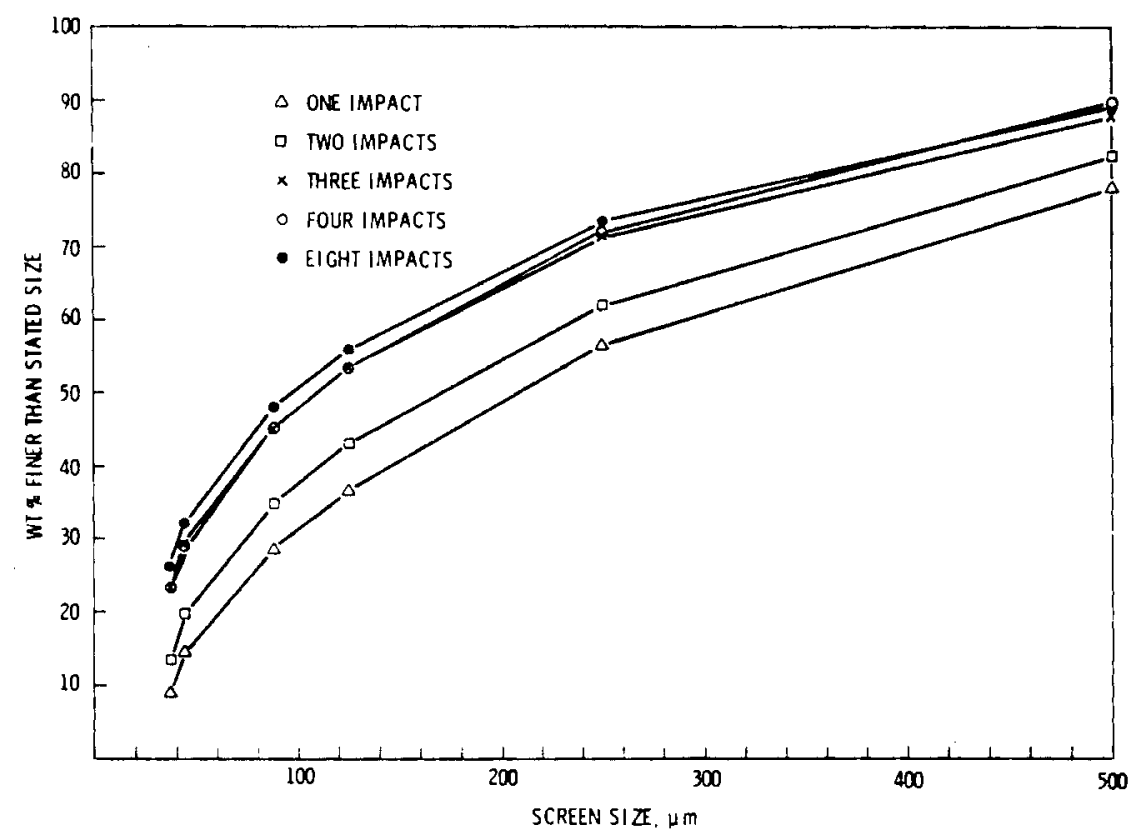

Figure 4. Sieve analysis results of multiple-impact testing.

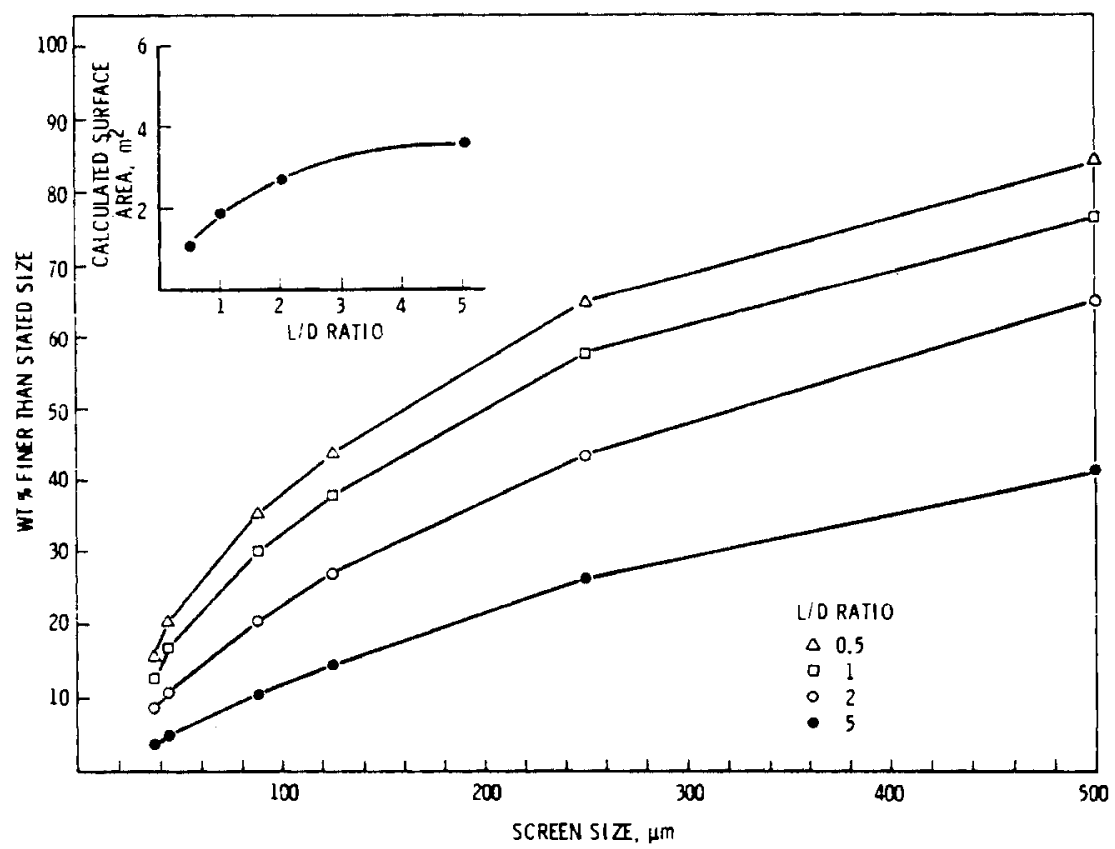

Figure 5. Sieve analysis results on soda-lime-silica glass of various $L / D$ ratios. The inset shows (calculated) surface area as a function of $L / D$ ratio. 


\section{A.3.4 Energy Equivalence Experiment.}

Since impact energy was used as a variable in much of this work, an experiment was done to demonstrate that, at least within a reasonable range, equivalent impact damage could be produced by various combinations of mass and drop height. To do the experiment, an energy of $113 \mathrm{~J}(83.2 \mathrm{ft}-1 \mathrm{~b})$ was produced by four combinations of mass and height. The sieving results are shown in Figure 6. It is seen that differences in particle sizing are small and show no systematic trend with mass and height. The difference in hammer velocity was not large in this case, only varying from 3.71 to $4.88 \mathrm{~m} / \mathrm{s}$. Larger differences in hammer velocity might produce somewhat different results, but the velocity used in our tests is within a factor of 10 of drop accidents $(13.4 \mathrm{~m} / \mathrm{sec}$ is attained in a $9.1 \mathrm{~m}$ free $\mathrm{fall})$ and shipping accidents [25 m/sec for a $90 \mathrm{~km} / \mathrm{h}(60 \mathrm{mph})$ truck]. Since the driving force for impact damage is a shock wave traveling at a sonic velocity in the solid, an order of magnitude variations in hammer velocity should not be a prime factor influencing glass fracturing.

\section{A.3.5 Effect of Devitrification on Impact Properties}

Properly performed, devitrification can strengthen glasses. For example, the tensile strength of devitrified Corning glass 9617 is roughly three times that of the same glass in the vitreous state. In the best case, devitrification results in a body approaching a fine-grained polycrystalline ceramic, with very little glassy phase remaining. Devitrified waste glass is also tougher under some conditions, as has been found by German workers. ${ }^{(3)}$ To evaluate the influence of devitrification, two glasses were impacted in both the vitreous and devitrified states.

The first glass examined was Corning Type 9617, a typical glass-ceramic. Specimens of this glass were tested in both the vitreous form and after devitrification according to a typical schedule $\left(800^{\circ} \mathrm{C}-31\right.$ min nucleation + $1150^{\circ} \mathrm{C}-60$ min growth). The material is $>90 \%$ crystalline after this treatment. Figure 7 shows a comparison of these two conditions with a standard soda-lime-silica glass at several energies ranging from 27 to $217 \mathrm{~J}$ (20-160 ft-1b). The devitrified product is marginally better than the 


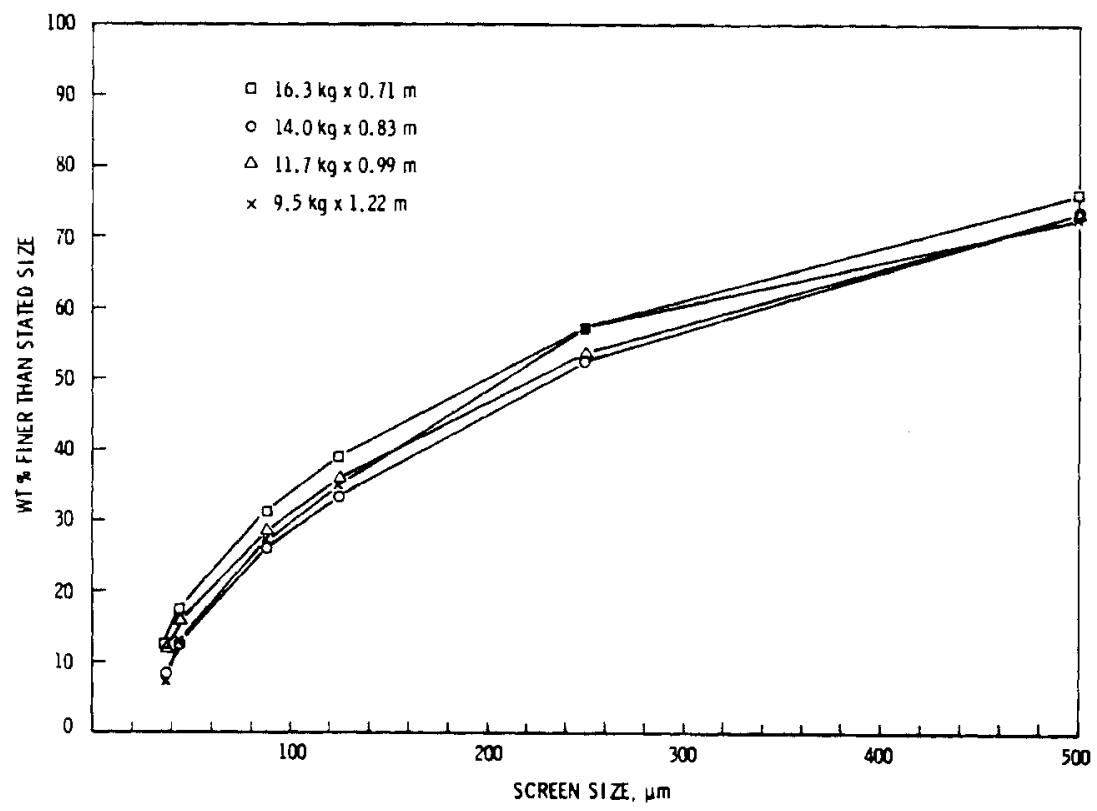

Figure 6. Sieve analysis results of equivalent energy delivered at different hammer velocity.

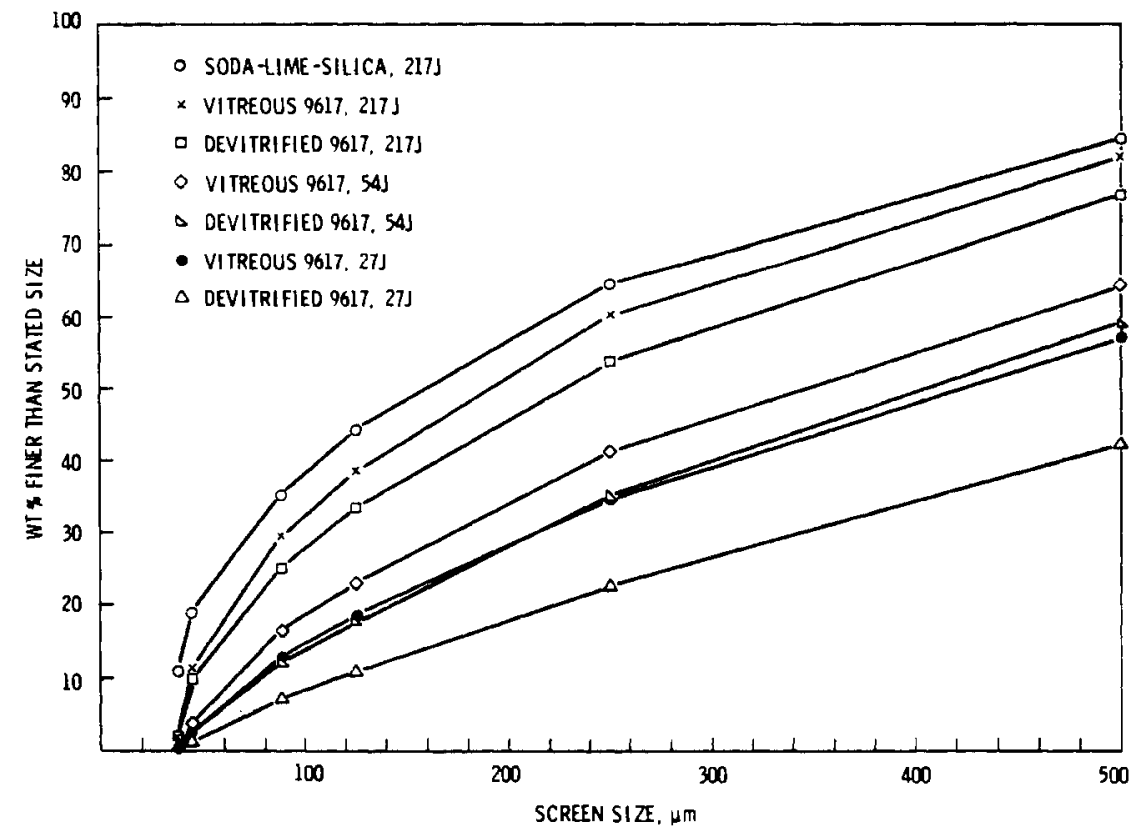

Figure 7. Sieve analysis results for vitreous and devitrified Corning 9617 glass at several impact energies. 
vitreous at high energies and improves with decreasing energy. It is noteworthy that results from both of the sample conditions of $9617 \mathrm{glass}$ are markedly superior to soda-lime-silica glass in terms of the amount of $-37 \mu \mathrm{m}$ fines, and are in fact the best observed in any of our glass impact work. This difference is apparently a result of composition. Since the Type 9617 specimens were only $0.64 \mathrm{~cm}$ thick, two pieces were used in each test. The soda-lime-silica was also tested in an identical configuration so that results would be comparable.

Comparison of vitreous versus partially devitrified simulated waste glass was made using composition 77-260, the AGNS glass. The vitreous specimens were prepared by melting at $1100^{\circ} \mathrm{C}$, then cooling $2 \mathrm{~h}$ in a $600^{\circ} \mathrm{C}$ furnace which was then shut off. Devitrified specimens were prepared by cooling from $1100^{\circ} \mathrm{C}$ at $6.25^{\circ} \mathrm{C} / \mathrm{h}$. This treatment resulted in about 30 vol\% crystals, mainly $\mathrm{Gd}_{2} \mathrm{Ti}_{2} \mathrm{O}_{7}$ and a rare earth apatite, $\mathrm{Ca}_{3}(\mathrm{RE})_{7}\left(\mathrm{SiO}_{4}\right)_{5}\left(\mathrm{PO}_{4}\right) \mathrm{O}_{2}$. Figure 8 shows sieving results after impact at $217 \mathrm{~J}$ and shows no noteworthy differences between the two specimen conditions in regard to impact performance.

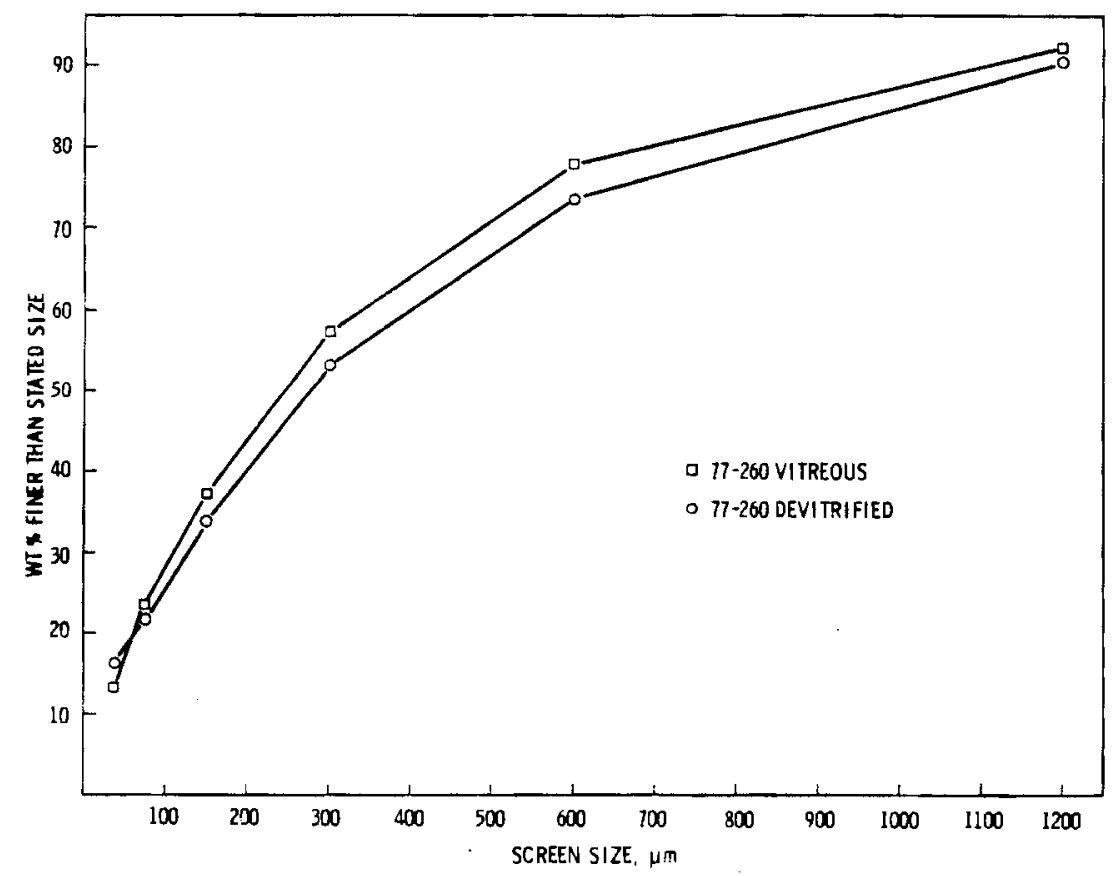

Figure 8. Sieve analys is results for Type 77-260 glass in the vitreous and devitrified state. 
The difference between these results and those of the German workers is probably explainable in terms of the impact severity. Their impact was $\sim 60 \mathrm{~J}$ and the specimen was substantially larger, about six times the volume of ours. The impact test used in our work is more severe because the relevant impacts are much greater than 60J. Earlier severe impact tests involving glass-filled canisters conducted at Pacific Northwest Laboratory, ${ }^{(1)}$ involving energies to $\sim 8200 \mathrm{~J}$ found no detectable difference between vitreous and devitrified simulated waste glasses. These glasses were not specifically designed or processed for devitrification as the German glasses were.

\section{A.3.6 Surface Area as a Function of Impact Energy}

During the impact event, some of the energy provided by the falling mass is used to create new surface area in the fracturing glass. For purposes of prediction, it would be convenient if there were a simple relationship between the amount of surface area created in a sample and the amount of energy involved in the impact. In order to see whether such a relationship existed, even for our lab-scale tests, two glasses, soda-lime-silica plate glass and ICM-11, were impacted over a fairly wide range of energies, 27 to 1900J. The surface areas of the resulting glass were determined by the B.E.T. technique. Results are plotted in Figure 9. Note that the impact damage in soda-limesilica is apparently described by a simple function, while that in ICM-11 glass appears to show a saturation of damage. The saturation may be because of the abundance of undissolved rare earth oxides present in this glass.

For both of these glasses, then, surface area is a fairly simple function of impact energy over the range of energies covered by lab-scale tests. The predictive capacity for large canisters is at present non-existent because of the difficulty of determining the fraction of the impact which actually would be used to crush glass, deform canister metal, rebound, etc. The present utility of the surface area versus energy correlation will be to compare different glasses.

It is also instructive to assess the fraction of the impact energy which actually was utilized in creating new surface area. The fracture surface energy of soda-lime-silica glass at room temperature is reported to be 


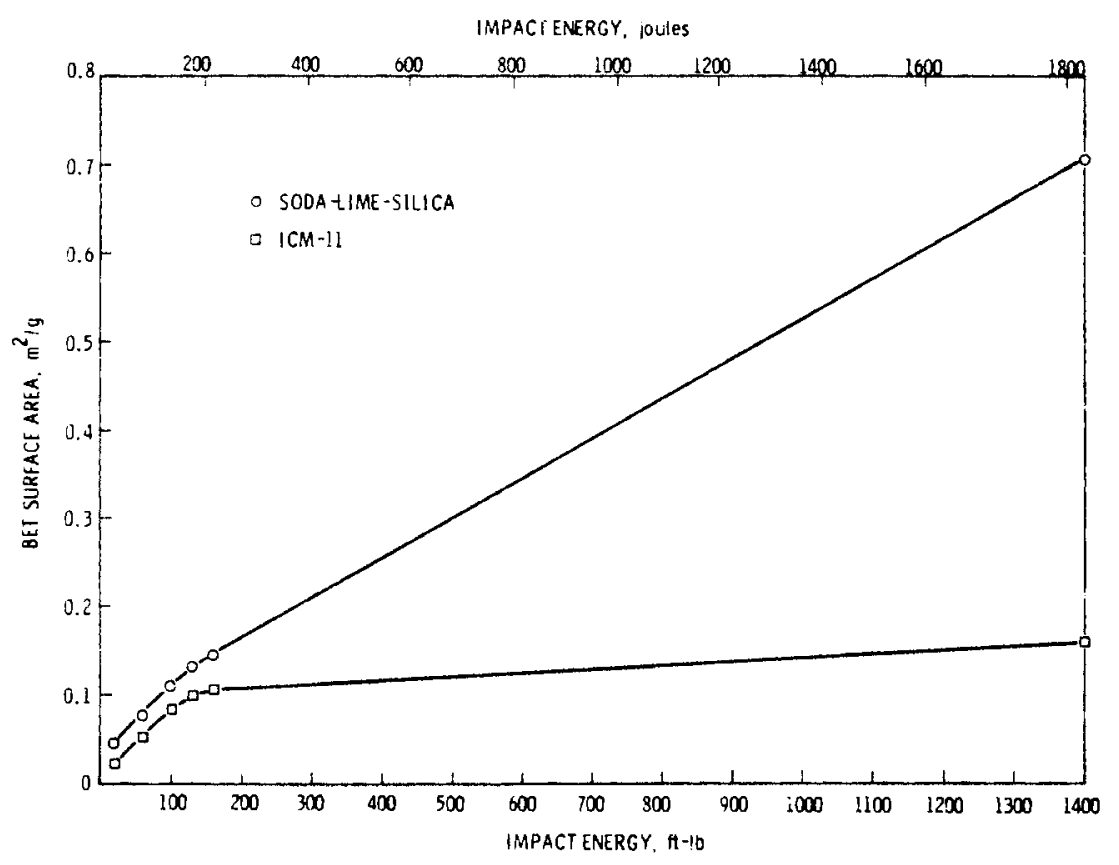

Figure 9. B.E.T. surface area as a function of impact energy for soda-lime-silica and ICM-11 glass.

$3.85 \mathrm{~J} / \mathrm{m}^{2} .{ }^{(4)}$ Based on the slope of the soda-lime-silica line in Figure 9, a surface energy of $1.1 \times 10^{-3} \mathrm{~m}^{2} / \mathrm{J}$ is calculated, indicating that only about $0.5 \%$ of the impact energy is used to create new surface area. The rest is apparently dissipated in other forms. Figure 10 shows results for glass ICM-11 and soda-lime-silica glass which were impacted at $217 \mathrm{~J}$, and simulated Hanford waste glass which was sampled from the most heavily damaged area of canister $\mathrm{KT}-14$, weighing $2000 \mathrm{~kg}$ and dropped $7.6 \mathrm{~m}$ (Energy $=1.5 \times 10^{5} \mathrm{~J}$ ).

\section{A.3.7 Fine Particle Sizes Produced by Impact}

Glass particles with a diameter less than ca. $10 \mu \mathrm{m}$ represent a respiration hazard. ${ }^{(5)}$ Sedimentation size analysis was used to evaluate the fraction present at this diameter. Figure 10 shows three curves representing three glasses under two impact conditions. ICM-11 [PW-4-b(2.0)73-1] and soda-lime-silica glasses were impacted at $217 \mathrm{~J}$, while simulated Hanford 


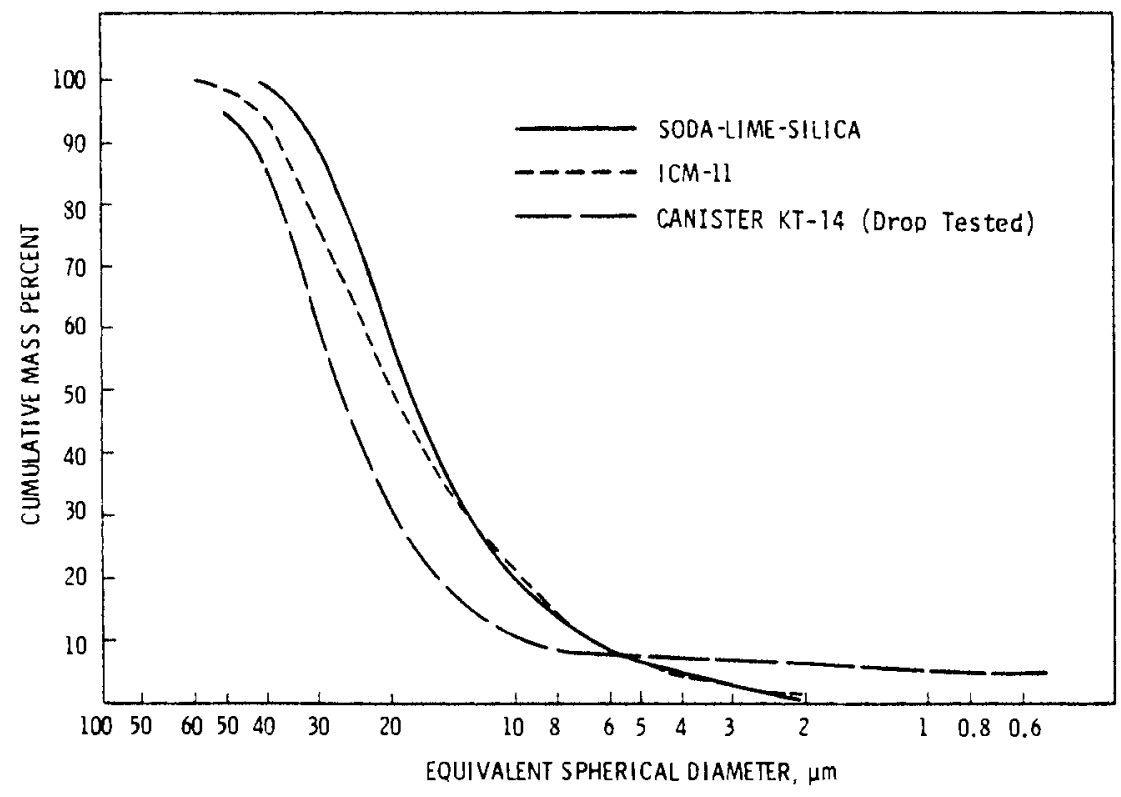

Figure 10. Subsieve size analysis for two glasses impacted in the lab test, as well as glass sampled from an actual drop test.

waste glass was sampled ( $\sim 5 \mathrm{wt} \%$ ) from the most heavily damaged area of canister KT-14, weighing $2000 \mathrm{~kg}$ and dropped $7.6 \mathrm{~m}$. The $-10 \mu \mathrm{m}$ fraction of the first two is fairly small at $(20 \%$ a $-44 \mu \mathrm{m} \times 14 \%$ a $-10 \mu \mathrm{m})=2.8 \%$ for soda-lime-silica glass. For ICM-11 glass, the fraction is $2.4 \%$. The respirable portion of the glass from canister $\mathrm{KT}-14$ is even smaller at $0.13 \%$. Apparently, these single-impact processes, even at high energies, are not very effective in producing fine particles.

\section{A.3.8 Glass Ranking}

Figure 11 is a compilation of sieving data on a variety of glasses, all impacted at an energy of $217 \mathrm{~J}$ and all of the same size and shape. Table 1 is a brief description of all the glasses. From the data, the following observations can be made:

(1) Fused $\mathrm{SiO}_{2}$ is the worst performer.

(2) Both 76-101 and 73-1 frits are superior in impact performance to the corresponding candidate waste glasses, 76-68 and 72-68 respectively. 


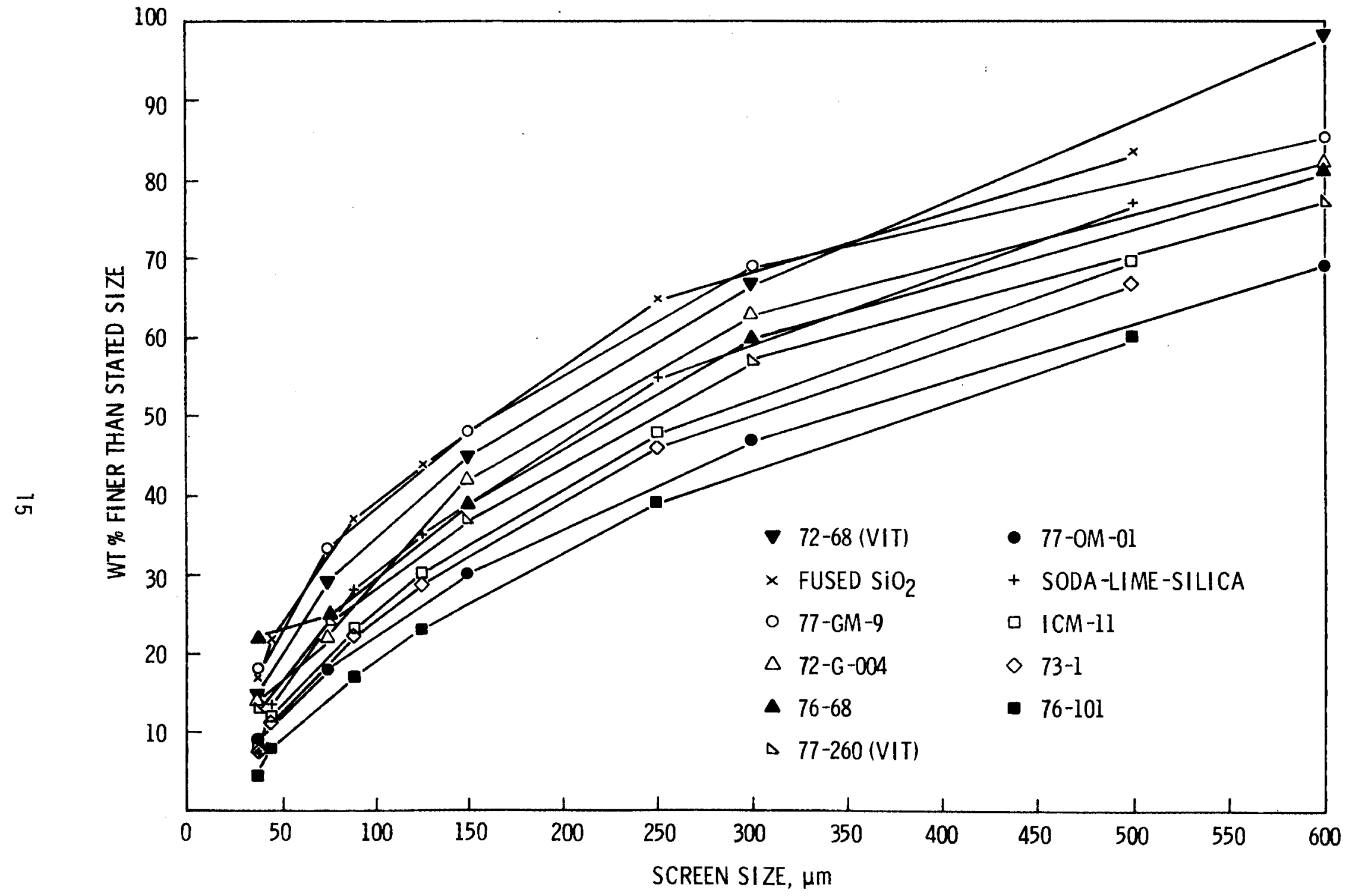

Figure 11. Plot of sieving data on a fairly wide variety of glasses. 
(3) Most waste glass compositions are similar in impact behavior.

(4) Soda-lime-silica glass is similar to many of the candidate waste glasses as regards impact behavior judged from sieving.

(5) The shape of the curves is very similar, the main difference being in the amount of fine particles generated.

It is quite common in glass science to correlate test results with factors such as the percentane of silica or the oxygen/silicon ratio. Good correlations have been made in the past with fundamental properties like density and elastic moduli. (6) An attempt was made to make such a correlation for the impact data. The weight percentage of fines less than $37 \mu \mathrm{m}$ in diameter was used as a rough Derformance index, and was plotted as a function of either silica content or $0 / \mathrm{Si}$ ratio. These are plotted in Figures 12 and 13; it is clear that no simple correlation with $0 / \mathrm{Si}$ ratio exists. The scatter implicit in the test $( \pm 5 \%)$ increases the difficulty of establishina clearcut correlations.

The line in Figure 12 indicates that some rough correlation might exist between silica content and fines generated. In the impact machine used for this work, abundant energy is available for specimen fracture. At the instant of failure, the specimen contains strain energy amounting to $\mathrm{K \sigma}_{f}{ }^{2} / 2 \mathrm{E}$ where $K=a$ constant, $\sigma_{f}=$ fracture stress and $E$ is Young's modulus. This energy is then converted to new surface area after the specimen fracture, which means that the higher the strain energy, the more fines will be produced. The shape of the line in Figure 12 would indicate that either the fracture strength goes through a minimum with silica content, or Young's modulus goes through a maximum. In the absense of any data on these properties for most of these glasses, the "relationship" is best regarded as fortuitous.

A word is in order regarding the general shape of the sieving curves in this report. Within the limits of the original sample size, the single impact of a brittle solid is regarded as a process which would ideally produce a classic bell-shaped distribution of particle sizes. Figure 14 shows three curves for typical glasses, and also includes a curve representing a cumulative Gaussian distribution. It is seen that there is not very much similarity in shape. When compared with the particle sizing occurring in other 


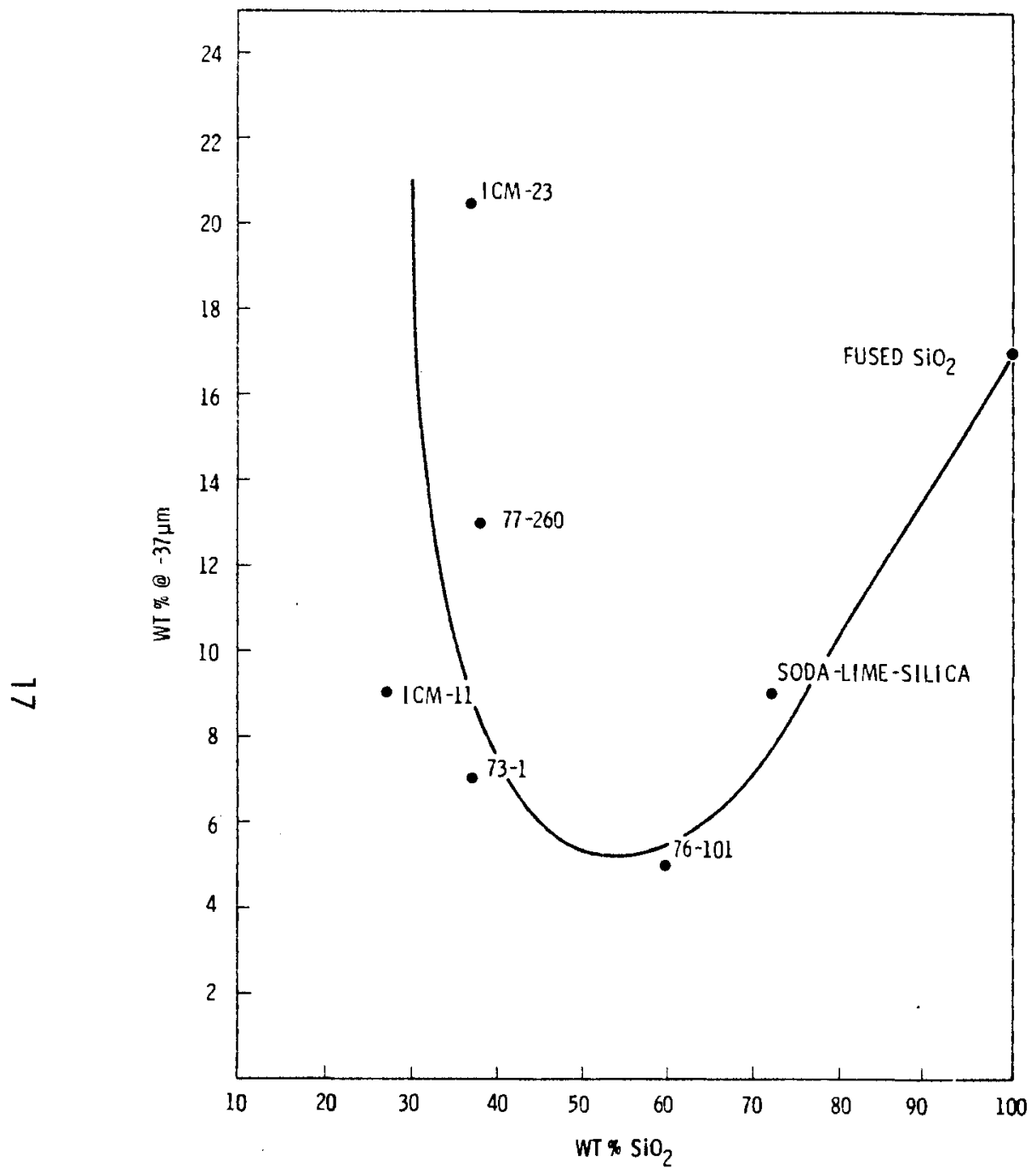

Figure 12. Attempted correlation of Impact damage as a function of silica content.

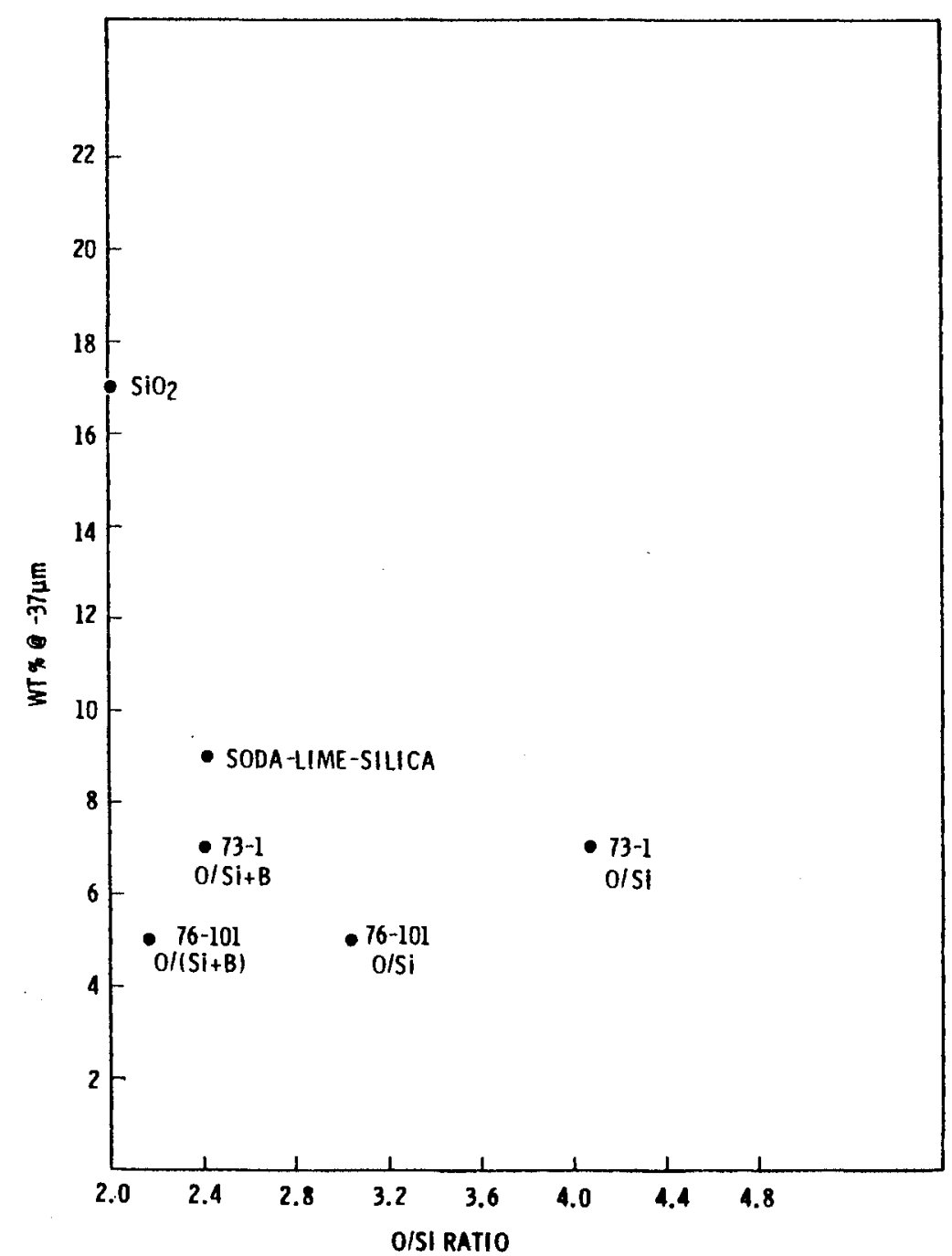

Figure 13. Same as Figure 12, except as a function of $0 / \mathrm{Si}$ ratio. 


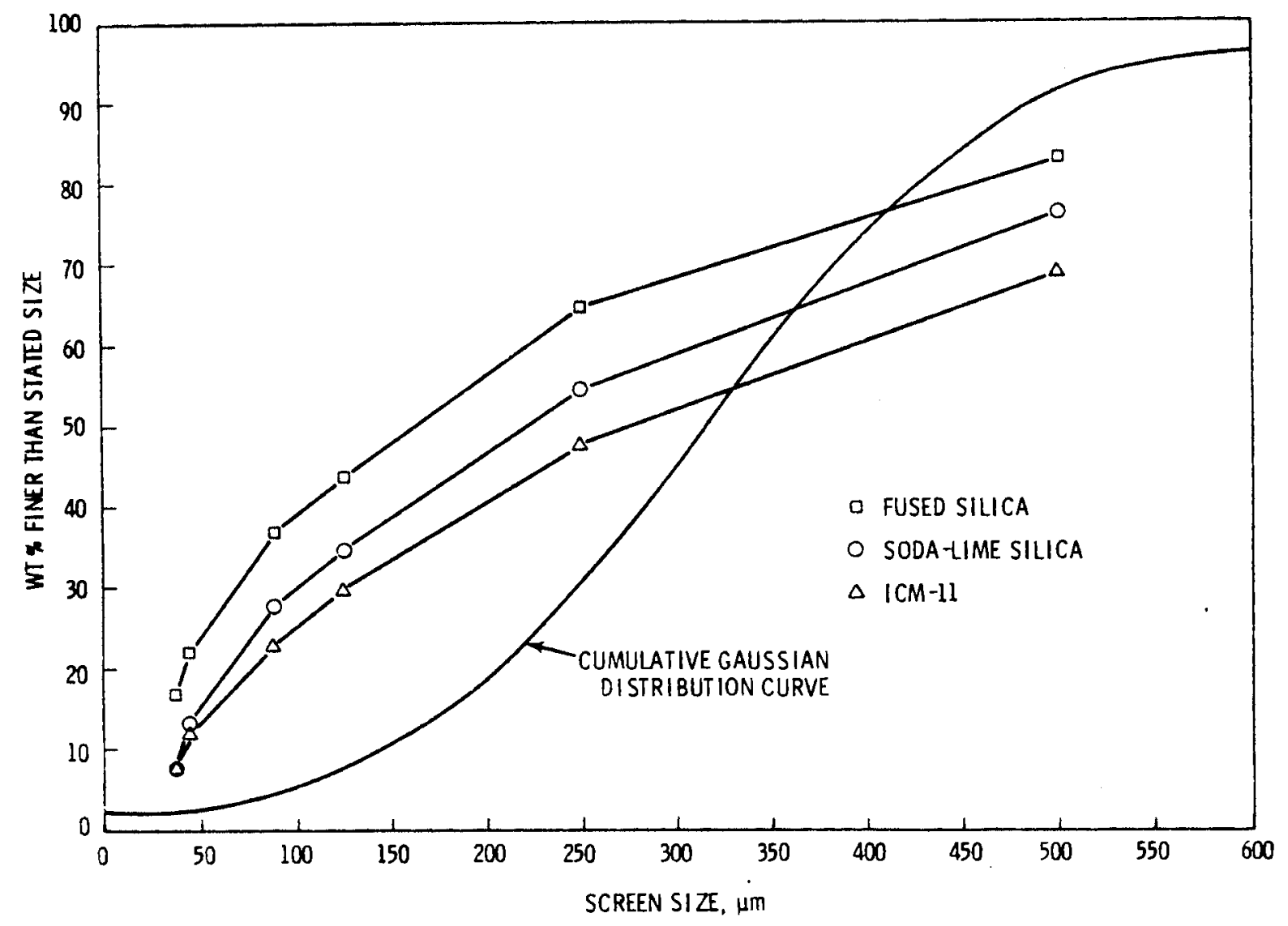

Figure 14. Sieve sizing data for three typical glasses, compared to Gaussian distribution.

size reduction processes such as bal1 mills, jaw crushers, and hammer mills, (7) the present data is closer to a Gaussian distribution than the output of any of these devices, which involve either multiple impacts and/or a mechanism for entrapping a particle and impacting it until it can pass through a gated opening. The single impact process does not involve this process of selection, but multiple impacts are probably present as the weight comes to rest. Also, the Gaussian curve is asymptotic at its end points, whereas all of our data must necessarily intersect the $(0,0)$ point. This intersection was not drawn in the curves shown here because the route taken to reach zero was unknown. 


\section{B.1 INTRODUCTION}

\section{B. TENSILE STRENGTH}

While the strength of the glass plays a role in the impact process, an impact serious enough for concern will fracture the glass; the concern in Section $A$ above is mainly one of extent and resultant particle size. In addition, the strength of the glass per se is relevant for long-term storage because of several factors:

1. Because the canisters are large, the glass will contain residual thermal stress in addition to those which will have caused cracking near the canister wall during fabrication. These stresses will also change as the amount of heat generated by radioactive decay decreases.

2. In the presence of water or water vapor, it is a we11-known fact $^{(8)}$ that glass exhibits static fatigue; that is, the stress to cause failure decreases with time.

3. Radiation-induced or devitrification-induced volume changes will produce additional stresses.

Consideration of the above points signals the need for at least some data on the strength of the waste glass. The objective of the work done on strength was to adapt a testing method such that it would be used even on highly radioactive glass with relative ease so these data could be collected.

\section{B.2 EXPERIMENTAL METHOD}

The "Strength" of a glass article is a rather nebulous quantity, and is a function of both the surface condition (strength-limiting flaws) and the testing method (volume of material under stress and knowledge of stress at failure site). The ceramic literature contains many good reviews of this subject; one of them is contained in Chapter 13 of Reference 6 . The objective of this work was to define a strength test yielding useful numbers for design and capable of at least detecting large deviations from baseline measurements which would result from such factors as devitrification, etc. 
The requirements of the strength test were that it would:

1. Require only a simple specimen geometry, one easy to obtain in a hot cell if desired.

2. Be self-aligning in a test fixture, so that only a minimum of critical handling would be involved and so that parasitic stresses would be eliminated. Parasitic stresses such as unknown bending moments can produce very misleading data in brittle materials.

3. Be an accepted method with at least some background in brittle materials.

In view of the above requirements, the test which emerged as the most feasible was the so-called Brazilian or splitting tensile test. It is used quite extensively for concrete (ASTM 946-64T) and has been used by other workers ${ }^{(9)}$ in the nuclear waste area for evaluating crystalline forms. The diagram of Figure 15 shows the test configuration. The specimen can be prepared simply by diamond-sawing to parallelism a core-drilled sample. It will roll for alignment between the parallel pressure plates of the test machine. The pads shown are a critical part of the test; they are used to prevent high point loading at the glass-platen contacts, which would cause crushing and premature failure. A number of materials were tried as pads, including aluminum, IBM cards, Teflon*, brass and several types of single-ply

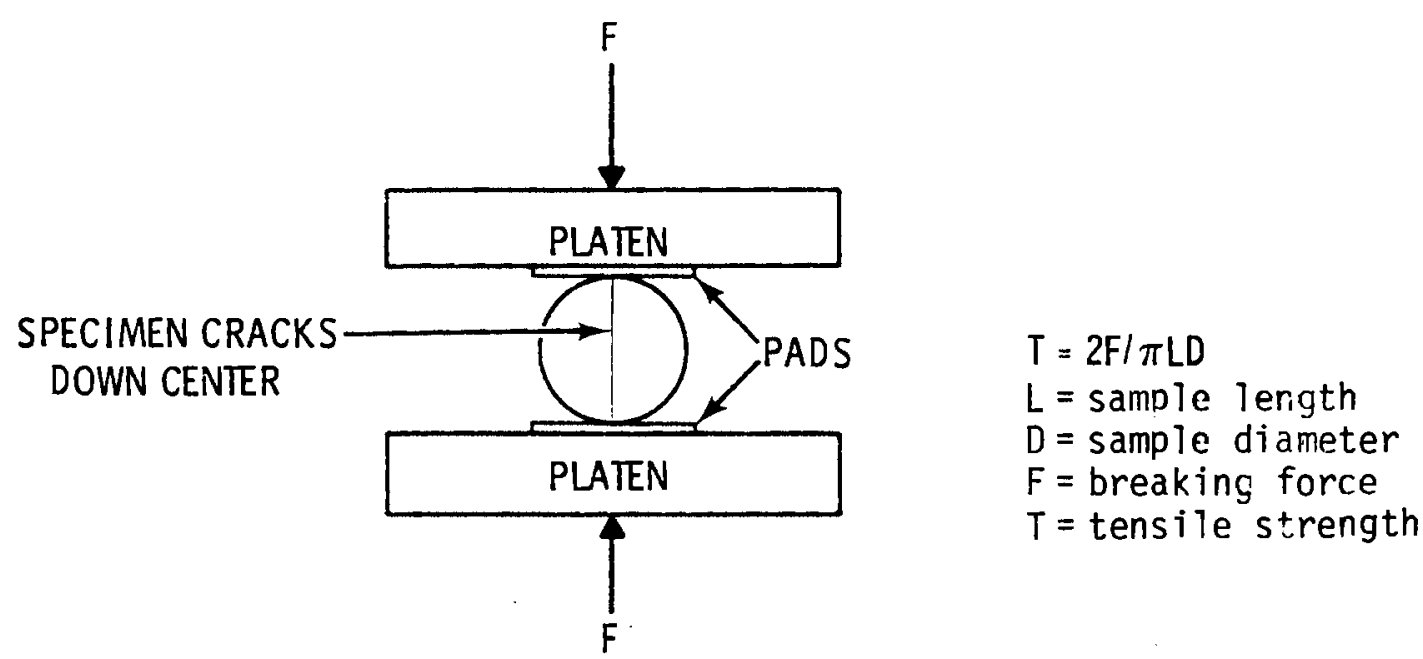

Figure 15. Diagram of experimental arrangement used in Brazilian splitting tensile test.

*duPont, WiTmington, DE. 
and multiple-ply wood. Balsa wood, with its grain oriented perpendicular to the line contact formed between cylinder and plate, was finally selected as the best pad material.

\section{B.3 RESULTS AND DISCUSSION}

The splitting tensile test was used on a group of soda-lime-silica glass rods as well as some core-drilled specimens of ICM-11 glass. An Instron* testing machine was used; the loading speed was $0.05 \mathrm{~cm} / \mathrm{min}$. The results are shown in Table 2. The standard deviations, while large, are not excessively so for glass testing. As a consequence, primarily of the large scatter, there is little if any difference between the measured strengths on a statistical basis (no difference at the 90\% leve1). The ICM-11 appears to be somewhat weaker, which would be expected from its rather large population of strengthlimiting flaws produced by undissolved rare earth oxides. Though the strength is marginally higher for the soda-lime-silica glass, the standard deviation is also higher. The splitting test is recommended as an evaluation of tensile strength of simulated and actual waste-containing glasses, as well as other homogeneous waste forms such as sintered supercalcine or devitrified glassceramic.

TABLE 2. Splitting Tensile Test Results

\begin{tabular}{|c|c|c|c|}
\hline Type of Glass & Number of Samples & $\begin{array}{c}\text { Average Strength } \\
\quad \mathrm{mPa} \text { (psi) }\end{array}$ & $\begin{array}{l}\text { Standard Deviation } \\
\quad \mathrm{mPa} \text { (psi) }\end{array}$ \\
\hline Soda-Lime-Silica & 32 & $47.67 \quad(6913)$ & $12.55(1820)$ \\
\hline ICM-11 & 29 & $37.18(5393)$ & 7.01 (1017) \\
\hline
\end{tabular}

*Instron Corp., Canton, MA. 


\section{A.4 CONCLUSIONS}

1. Compositional changes within the ranges expected for wastecontaining glasses are not likely to have a large effect on impact performance.

2. In the range of energies tested, devitrification has little effect on impact performance.

3. The impact test is sufficiently specimen geometry dependent to justify caution when changing configurations used in lab-scale tests.

4. In the range of energies tested, surface area of generated particles was a simple function of impact energy for soda-lime-silica and a simulated waste-containing glass.

\section{B.4 CONCLUSIONS}

The Brazilian or splitting tensile test is applicable for strength determination on waste glasses and meets the requirements for such a test.

\section{ACKNOWLEDGMENT}

This work was performed for the U.S. Department of Energy under Contract EY-76-C-06-1830. The technical assistance of S. D. Tomich and R. A. Wheeler in the conduct of this work is gratefully acknowledged. 


\section{REFERENCES}

1. T. H. Smith and W. A. Ross, Impact Testing of Vitreous Simulated High-Level Waste in Canisters, BNWL-1903, Pacific Northwest Laboratory, (May, 1975).

2. R. M. Wallace and J. A. Kelley, An Impact Test for Solid Waste Forms, DP-1400 Savannah River Laboratories (March 1976).

3. A. K. De, B. Luckscheiter, W. Lutze, G. Malow, and E. Schiewer, "Development of Glass Ceramics for the Incorporation of Fission Products," Amer. Cer. Soc. Bu1l. 55(5) (1976).

4. S. M. Wiederhorn, "Fracture Surface Energy of Glass, Journal Amer. Cer. Soc. $\underline{52}$ (2) 99 (1969).

5. T. T. Mercer, Aerosol Technology in Hazard Evaluation, Academic Press (1973).

6. G. W. Morey, The Properties of Glass, Second Edition, Reinhold Publishing Corp., pp 305, 272,224 (1954).

7. C. G. Lowrison, Crushing and Grinding, The Size Reduction of Solid Materials, CRC Press, p 71 (1974).

8. E. Orowan, "The Fatigue of Glass Under Stress," Nature, 154, 341 (September 9, 1944).

9 R. H. Marion and J. K. Johnstone, Parametric Study of the Diametral Compression Tests for Ceramics, SAND-75-0347, Sandia Laboratories (July 1975). 

APPENDIX A

Compositions of Glasses Tested 
APPENDIX A. APPROXIMATE COMPOSITION ${ }^{\mathrm{a}}$ OF GLASSES TESTED

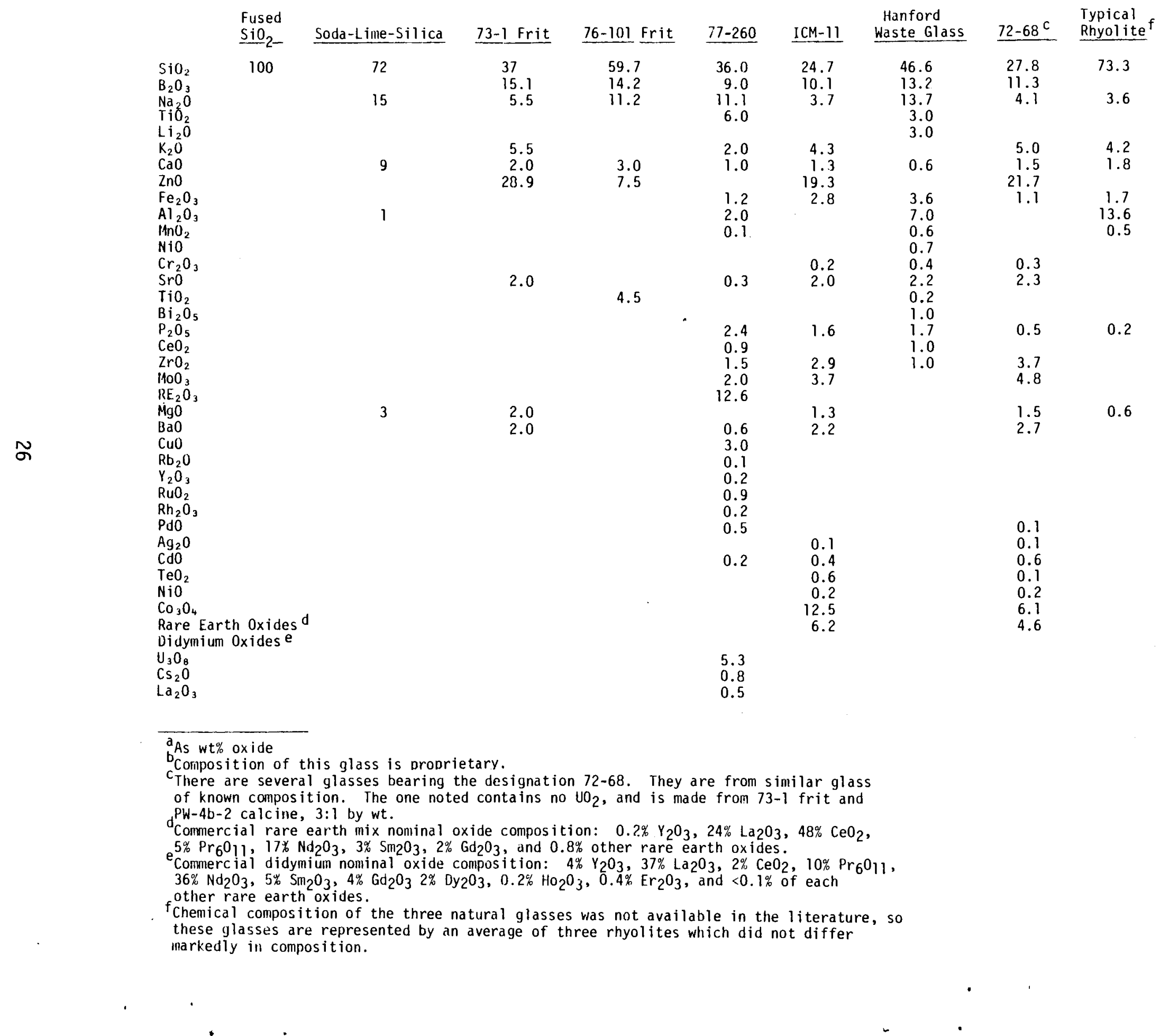




\section{DISTRIBUTION}

No. of

Copies

\section{UNITED STATES}

A. A. Churm

DOE Chicago Patent Division

9800 South Cass Avenue

Argonne, IL 60439

R. E. Cunningham

Deputy Director for Fuels and Materials

Nuclear Regulatory Commission

Silver Springs, MD 20910

Assistant Director for Radioactive Waste Management Branch

NRC Division of Materials and

Fuel Cycle Facility Licensing

Washington, DC 20545

D. M. Rohrer

United States Nuclear Regulatory Commission

Washington, DC 20555

John Martin

United States Nuclear Regulatory Commission

Washington, DC 20555

W. G. Belter

DOE Division of Biomedical and

Environmental Research

Earth Sciences Branch

Washington, DC 20545

W. A. Brobst

DOE Division of Environmental

Control Technology

Washington, DC 20545
No. of

Copies

W. E. Mott

DOE Division of Environmental Control Technology

Washington, DC 20545

R. B. Chitwood

DOE Division of Nuclear Power Development

Washington, DC 20545

T. C. Chee

DOE Office of Nuclear Waste Management

Washington, DC 20545

C. R. Cooley

DOE Office of Nuclear Waste Management

Washington, DC 20545

She idon Meyers

DOE Office of Nuclear Waste Management

Washington, DC 20545

R. G. Romatowski

DOE Office of Nuclear Waste Management

Washington, DC 20545

C. A. Heath

DOE Office of Nuclear Waste Management

Washington, DC 20545

G. Oertel

DOE Office of Nuclear Waste Management

Washington, DC 20545 
No. of

Copies

\author{
A. F. Perge \\ DOE Office of Nuclear Waste \\ Management \\ Washington, DC 20545 \\ D. L. Vieth \\ DOE Office of Nuclear Waste \\ Management \\ Washington, DC 20545 \\ R. D. Walton \\ DOE Office of Nuclear Waste \\ Management \\ Washington, DC 20545 \\ J. Neff, Program Manager \\ Department of Energy \\ Columbus Program Office \\ 505 King Avenue \\ Columbus, $\mathrm{OH} 43201$
}

J. B. Whitsett

DOE Idaho Operations Office

P.0. Box 2108

Idaho Falls, ID 83401

John Van Cleve

DOE Oak Ridge Operations Office

P.0. Box X

Oak Ridge, TN 37830

E. S. Goldberg

DOE Savannah River Operations Office

P.0. Box A

Aiken, SC 29801

27 DOE Technical Information Center

A. P. Roeh, Manager

Allied Chemical Corporation

550 2nd Street

Idaho Falls, ID 83401
No. of

Copies

J. R. Berreth

Allied Chemical Corporation 550 2nd Street

Idaho Falls, ID 83401

R. A. Brown

Allied Chemical Corporation 550 2nd Street

Idaho Falls, ID 83401

C. A. Hawley

Allied Chemical Corporation 550 2nd Street

Idaho Falls, ID 83401

D. A. Knecht

Allied Chemical Corporation 550 2nd Street

Idaho Falls, ID 83401

Allied Chemical Corporation

(File Copy)

550 2nd Street

Idaho Falls, ID 83401

M. D. McCormack

E.G. \& G.Idaho, Inc.

P.0. Box 1625

Idaho Falls, ID 83401

W. C. Seymour

E.G. \& G. Idaho, Inc.

P.0. Box 1625

Idaho Falls, ID 83401

R. A. Buckham

Allied-General Nuclear Service P.0. Box 847

Barnwell, SC 29812

A. Williams

Allied-General Nuclear Service P.0. Box 847

Barnwe 11, SC 29812 
No. of

Copies

Keith Flynn

Argonne National Laboratory 9700 South Cass Avenue

Argonne, IL 60439

J. L. Jardine

Argonne National Laboratory

9700 South Cass Avenue

Argonne, IL 60439

M. M. Steindler/L. E. Trevorrow

Argonne National Laboratory

9700 South Cass Avenue

Argonne, IL 60439

J. M. Batch

Battelle Memorial Institute 505 King Ave.

Columbus, $\mathrm{OH} 43201$

Wayne Carbiener

Battelle Memorial Institute 505 King Ave.

Columbus, $\mathrm{OH} 43201$

J. D. Duguid

Battelle Memorial Institute 505 King Ave.

Columbus, $\mathrm{OH} 43201$

R. E. Heineman

Battelle Memorial Institute 505 King Ave.

Columbus, $\mathrm{OH} 43201$

Battelle Memorial Institute Office of Nuclear Waste I solation

Attn: Beverly Rawles

505 King Avenue

Columbus, $\mathrm{OH} 43201$
No. of

Copies

J. Kircher

Office of Nuclear Waste Isolation

Battelle Memorial Institute

505 King Ave.

Columbus, $\mathrm{OH} 43201$

Don Moak

Battelle Memorial Institute

505 King Ave.

Columbus, $\mathrm{OH} 43201$

Ken Yates

Battelle Memorial Institute 505 King Ave.

Columbus, $\mathrm{OH} 43201$

Brookhaven National Laboratory

Reference Section

Information Division

Upton, NY 11973

Paul W. Levy

Brookhaven National Laboratory Upton, NY 11973

M. Ste inberg

Brookhaven National Laboratory

Upton, NY 11973

Combustion Division

Combustion Engineering, Inc.

Windsor, CT 06095

B. Adams

Corning Glass Works

Technical Staffs Division

Corning, NY 14830

E. Vejvoda, Director

Chemical Operations

Rockwe 11 International

Rocky Flats Plant

P.0. Box 464

Golden, CO 80401 
No. of

Copies

J. L. Cranda 11

E. I. duPont DeNemours and Company

Savannah River Laboratory

Aiken, SC 29801

H. L. Hul1

E. I. duPont DeNemours and Company

Savannah River Laboratory

Aiken, SC 29801

R. G. Garvin

E. I. duPont DeNemours and Company

Savannah River Laboratory

Aiken, SC 29801

D. L. McIntosh

E. I. duPont DeNemours and Company

Savannah River Laboratory

Aiken, SC 29801

J. A. Kelley

E. I. duPont DeNemours and Company

Savannah River Laboratory

Aiken, SC 29801

S. D. Harris, Jr.

E. I. duPont DeNemours and Company

Savannah River Laboratory

Aiken, SC 29801

Robert Maher

E. I. duPont DeNemours and Company

Savannah River Laboratory

Aiken, SC 29801
No. of

Copies

S. Mirschak

E. I. duPont DeNemours and Company

Savannah River Laboratory

Aiken, SC 29801

J. K. Okeson

E. I. duPont DeNemours and Company

Savannah River Laboratory

Aiken, SC 29801

M. S. Plodinec

E. I. duPont DeNemours and Company

Savannah River Laboratory

Aiken, SC 29801

A. S. Jenn ings

E. I. duPont DeNemours and Company

Savannah River Laboratory

Aiken, SC 29801

Leon Meyers

E. I. duPont DeNemours and Company

Savannah River Laboratory

Aiken, SC 29801

H. Henning

Electric Power Research

Institute

3412 Hillview Avenue

P.0. Box 10412

Palo Alto, CA 94301

Environmental Protection Agency

Technology Assessment Division

(AW-559)

Office of Radiation Programs

Washington, DC 20460 
R. G. Barnes

General Electric Company

175 Curtner Avenue (M/C 858)

San Jose, CA 95125

L. H. Brooks

Gulf Energy and Environmental Systems

P.0. Box 81608

San Diego, CA 92138

D. C. Fulmer

Savannah River Operations Office P.0. Box A

Aiken, SC 29801

3 Los Alamos Scientific Laboratory (DOE)

P.0. Box 1663

Los Alamos, NM 87544

C. J. Kershner

Monsanto Research Corporation

Mound Laboratory

P.0. Box 32

Miamisburg, $\mathrm{OH} 45342$

John Pomeroy

Technical Secretary

National Academy of Sciences

Committee of Radioactive Waste

Management

National Research Council

2101 Constitution Avenue

Washington, DC 20418

Stewart Farber

New Eng? and Fower Company

280 Melrose Street

Providence, Rhode Island 02901
2 J. P Duckworth

Plant Manager

Nuclear Fuel Services, Inc.

P.0. Box 124

West Valley, NY 14171

J. G. Cline, General Manager

NYS Energy Research and Development Authority

230 Park Avenue, Rm 2425

New York, NY 10017

2 Oak Ridge National Laboratory (DOE)

Central Research Library Document Reference Section P.0. Box $X$

Oak Ridge, TN 37830

E. H. Kobish

Solid State Division

Oak Ridge National Laboratory

Oak Ridge, TN 37830

G. J. McCarthy

Pennsylvania State University

Materials Research Laboratory

University Park, PA 16802

Professor Guna Salvaduray

Materials Engineering

San Jose State University

San Jose, CA 95192

D. R. Anderson

Sandia Laboratories

Albuquerque, NM 87107

J. K. Johnstone

Sandia Laboratories

Albuquerque, NM 87107 
No. of

Copies

W. Weart

Sandia Laboratories

Albuquerque, NM 87107

J. Sivinshi

Sandia Laboratories

Albuquerque, NM 87107

J. 0. Blomeke

Union Carbide Corporation (ORNL)

Chemical Technology Division

P.0. Box $Y$

Oak Ridge, TN 37830

R. E. Blanco

Union Carbide Corporation (ORNL)

Chemical Technology Division

P.0. Box $Y$

Oak Ridge, TN 37830

E. Newman

Union Carbide Corporation (ORNL)

Chemical Technology Division

P.0. Box $Y$

Oak Ridge, TN 37830

A. L. Lotts

Union Carbide Corporation (ORNL)

Chemical Technology Division

P.0. Box $Y$

Oak Ridge, TN 37830

W. J. Lackey

Union Carbide Corporation (ORNL)

Chemical Technology Division

P.0. Box Y

Oak Ridge, TN 37830

$T$. Lindemer

Union Carbide Corporation (ORNL)

Chemical Technology Division

P.0. Box $Y$

Oak Ridge, TN 37830
No. of

Copies

D. E. Ferguson

Union Carbide Corporation (ORNL)

Chemical Technology Division

P.0. Box Y

Oak Ridge, TN 37830

H. W. Godbee

Union Carbide Corporation (ORNL)

Chemical Technology Division

P.0. Box $Y$

Oak Ridge, TN 37830

W. C. McClain

Union Carbide Corporation (ORNL)

Chemical Technology Division

P.0. Box $Y$

Oak Ridge, TN 37830

R. A. Beall

U. S. Department of Interior Bureau of Mines

Albany Research Center

1450 W. Queen Avenue

Albany, OR 97321

D. B. Stewart

U. S. Department of Interior

959 National Center

Geological Survey

Reston, Virginia 22092

R. G. Post

College of Engineering

University of Arizona

Tucson, AZ 85721

S. E. Logan

Los Alamos Technical Associates, Inc.

P.0. Box 410

Los Alamos, NM 87544 
No. of

Copies

FOREIGN

2 International Atomic Energy Agency

Kartner Ring 11

P.0. Box 590

A-1011, Vienna, AUSTRIA

Rene Amavis

EURATOM

Health Physics Division

29, Rue Aldringer

Luxembourg, BELGIUM

G. G. Strathdee

Atomic Energy of Canada, Ltd.

W.N.R.E. Pinawa, Manitoba

ROE ILO

CANADA

M. Tomlinson

Director of Chemistry and

Materials Science Division

Atomic Energy of Canada Ltd.

Whiteshell Nuclear Research

Est abl ishment

Pinawa, Manitoba, CANADA

K. D. B. Johnson

Atomic Energy Research

Establishment, Harwe 11, Didcot, Berks, ENGLAND

J. A. C. Marples

Atomic Energy Research

Establishment

Harwe 11, Didcot,

Berks, ENGLAND

D. W. Clelland

United Kingdom Atomic Energy

Authority

Risley, ENGLAND
No. of

Copies

\author{
P. J. Regnaut \\ Centre d'Etudes Nucleaires de \\ Fontenay-aux Roses \\ Boite Postale 6 \\ 92 - Fontenay-aux Roses \\ FRANCE
}

Dr. P. G. Alfredson

Chief, Chemical Technology Division

Australian Atomic Energy Commission

Research Establishment

Lucas Heights, New South Wales, 2232

Library

Studsvik Energiteknik $A B$

S-611 01Nykoping

SWEDEN

Bundesministerium fur Forschung und Technologie

Stressemannstrasse 2

5300 Bonn

WEST GERMANY

Center for Atomic Energy

Documentation (ZAED)

Attn: Dr. Mrs. Bell

P. 0. Box 3640

$7500 \mathrm{Kar}$ lsruhe

WEST GERMANY

Hans W. Levi

Hahn-Meitner Institut

1 Berlin 39

Glien ickerstr. 100

WEST GERMANY 
No. of

Copies

FOREIGN

E. R. Merz

Institut fur Chemische

Technologie

Kernforschungsanloge Julich

$\mathrm{GmbH}$

D517 Julich

Postfach 365

Federal Republic

WEST GERMANY

R. Bonniaud

Center de Marcoule

B.P. 170

30200 Baguols-Sur-Ceze

FRANCE

C. Sombret

Centre de Marcoule

B.P. 170

30200 Baguols-Sur-Ceze

FRANCE

F. Laude

Centre de Marcoule

B.P. 170

30200 Baguols-Sur-Ceze

FRANCE

2 H. Krause

Kernforschungszentrum Kar lsruhe GmbH (KfK)

Postfach 3640

D7500 Kar lsruhe WEST GERMANY

R. V. Amalraj

C.W.M.F. Project

P.0. Kalpakkam

Chingleput Dist.

Tami1 Nadu, INDIA
No. of

Copies

N. S. Sunder Rajan

Bhabha Atomic Research Centre

Goverment of India

Hall No. 5

Trombay

Bombay 85

INDIA

Dr. Piero Risoluti,

AGIP NUCLEARE

c/o COMB Casaccia

C.P. 2400

Rome

ITALY

F. Gera

CHEN

CSN Casaccia L.I.S.

C.P. 2400, 00100

Rome

ITALY

S. Tashiro

Japan Atomic Energy Research Institute

Environmental Safety Research Laboratory

1-1-13, Shibashi

Minatopku, Tokyo

JAPAN

\section{ONSITE}

4 DOE Richland Operations Office

P. A. Craig

H. E. Ransom

M. W. Shupe

M. J. Zamorski 
ONSITE

11 Rockwell Hanford Operations

H. Badad

R. A. Deju

R. J. Gimera

J. D. Kaser

E. J. Kosiancic

M. J. Kupfer

C. M. Manry

J. H. Roecker

W. W. Schultz

D. D. Wodrich

File copy

3 Exxon Nuclear Company

S. J. Beard

Joint Center for Graduate Study

J. Cooper

2 United Nuclear Industries, Inc.

T. E. Dabrowski

A. E. Engler

Westinghouse Hanford Company

A. G. Blasewitz

78 Pacific Northwest Laboratory

S. M. Barnes

W. J. Bjorklund

H. T. Blair

W. F. Bonner

D. J. Bradley

A. Brandstetter
R. A. Brouns

J. B. Brown, Jr.

J. L. Buelt

R. L. Bunnel1 (10)

H. C. Burkholder

L. A. Chick

T. D. Chikalla

M. 0. Cloninger

R. D. Dierks

J. W. Finnigan

W. J. Gray

M. S. Hanson

J. C. Hart 1

M. H. Henry (3)

O. F. Hill

L. K. Holton

J. H. Jarrett

Y. B. Katayama

W. S. Kelly

R. S. Kemper

D. E. Knowlton

D. K. Kreid

W. L. Kuhn

D. E. Larson

J. M. Lukacs

R. P. Marshall

S. A. McCullough

J. L. MCElroy (3)

J. S. McPherson

G. B. Mellinger

J. E. Mendel

F. A. Miller

R. E. Nightingale

D. E. Olesen

C. R. Palmer

A. M. Platt

D. L. Prezbindowski (2)

F. P. Roberts

W. A. Ross

J. M. Rusin

D. H. Siemens

S. C. Slate

R. T. Treat

R. P. Turcotte (2) 
No. of

Copies

ONSITE

H. H. Van Tuyl

J. W. Voss

J. W. Wald/W. E. Weber

J. H. Westsik, Jr.

L. D. Williams

W. K. Winegardner

Technical Information (5)

Publishing Coordination (2) 